\title{
KNOWLEDGE AND PRACTICES OF MIDWIVES REGARDING ZIKA VIRUS IN KENDARI, SOUTHEAST SULAWESI, INDONESIA
}

\section{Ramadhan Tosepu ${ }^{1}$, Indri Eka Artamevia Khaerun Nisa Patawari ${ }^{1}$, Hariati Lestari ${ }^{2}$, Siti $^{2}$ Rabbani Karimuna ${ }^{1}$, La Ode Muhamad Sety ${ }^{2}$, Fifi Nirmala ${ }^{3}$}

\author{
${ }^{1}$ Department of Environmental Health, Faculty of Public Health, University of Halu Oleo, Southeast Sulawesi, Indonesia \\ ${ }^{2}$ Department of Epidemiology, Faculty of Public Health, University of Halu Oleo, Southeast Sulawesi, Indonesia \\ ${ }^{3}$ Department of Health Nutrition, Faculty of Public Health, University of Halu Oleo, Southeast Sulawesi, Indonesia
}

Received: 16 June 2020 | Accepted: 8 September 2020

DOI: https://dx.doi.org/10.36685/phi.v6i3.344

\section{Correspondence:}

Ramadhan Tosepu, SKM., M. Kes., PhD

Department of Environmental health

Faculty of Public Health, University of Halu Oleo,

Southeast Sulawesi, Indonesia

Jl.H.E. Mokodompit, Anduonohu.

Email: ramadhan.tosepu@uho.ac.id

Copyright: (C) 2020 the author(s). This is an open-access article distributed under the terms of the Creative Commons Attribution Non-Commercial License, which permits unrestricted non-commercial use, distribution, and reproduction in any medium, provided the original work is properly cited.

\begin{abstract}
Background: In 2016 Zika virus infection became an international public health emergency concern.

Objective: This study aimed to evaluate the knowledge and practice of midwives regarding the Zika virus.

Methods: This research was an analytic study with a cross-sectional approach. A total of samples was 191 selected using a proportional random sampling technique. WHO questionnaire was used to collect data on knowledge and practice related to the Zika virus and a set of explanatory variables.

Results: The midwife's knowledge of the Zika virus revealed that only the workplace and sources of information were associated with knowledge of the Zika virus infection. Public health center had a greater chance of having good knowledge than hospitals with OR: 5.130 (CI: 2.591-10.157) and first knew Zika information more than one year ago had a greater chance of having good knowledge than the first midwife knew about Zika on the day the study was conducted with OR: 3.035 (CI: 1.485-6.203).

Conclusion: Knowledge and practice regarding Zika virus infection among midwives in Kendari city Indonesia was relatively good. Furthermore, midwives who work in the public health center had a five times chance compared to midwives who work in hospitals to have better knowledge related to the Zika virus.
\end{abstract}

Keywords: Zika virus, knowledge, practice, midwife, Kendari, Indonesia

\section{BACKGROUND}

Zika virus is one type of arbovirus from the genus Flavivirus (Samuel et al., 2018). This virus has a very close phylogenetic relationship with other arboviruses such as dengue and yellow fever (Choi \& Kim, 2018). This virus first identified in 1947, which found in the saliva of monkeys in yellow fever. This virus was first known to infect humans in 1952 in Uganda and Tanzania (Ioos et al., 2014). Extraordinary events were first reported in 2007 in the Pacific region. Then it was reported several times outbreaks in Asia, Africa, the Regional Western Pacific region, and most recently occurred in America (Duong, Dussart, \& Buchy, 2017; Painter, Plaster, Tjersland, \& Jacobsen, 2017). 
Indonesia has found a case of Zika virus infection, which in Jambi. Evidence of this virus infection was found from December 2014 to April 2015 due to an increase in the incidence of dengue. Of the 103 blood samples diagnosed with dengue fever, there was one blood sample that not found to indicate dengue. Then after further examination, it was found that the Zika virus detected in the patient sample. But experts concluded that the Zika virus had indeed developed in the Jambi area and had already infected the population there; however, residents considered it to be dengue fever because of the symptoms caused by similar (Perkasa et al., 2016).

On 1 February 2016, the Zika virus infection was declared a public health emergency of international concern by the World Health Organization (World Health Organization, 2016b). In Kendari City, Zika outbreaks have not reported to date. However, it is susceptible to the Zika outbreak, given that there is already evidence that shows that the Zika virus already exists in Indonesia. Zika virus vector is the same as the dengue fever vector, namely Aedes aegypti mosquito. Co-circulation of the Zika virus with dengue and chikungunya viruses is most likely to occur in all endemic areas (Musso et al., 2014). Indonesia is one of the largest dengue-endemic countries and has experienced several outbreaks of chikungunya fever and inhabited by Aedes aegypti and Aedes albopictus mosquitoes (Kendrick, 2016).

Zika virus infection in adults-only shows mild symptoms in $20 \%$ of infected patients (Haddow et al., 2012). Zika virus infection is a self-limiting disease because it will heal itself within 2-7 days. Clinical manifestations that arise in someone infected with Zika virus are similar to DHF, which are fever, headache, rash, inflammation of the eyes, pain in the muscles, and pain in the joints (Tosepu, 2016). However, there is a recent report from the Brazilian Ministry of Health showing a possible relationship between Zika virus infection in pregnancy and fetal malformations because there have been found cases of microcephalus in about 20 newborns in northeast Brazil(Noor \& Ahmed, 2018).
Microcephalus can define as a clinical finding, the results of measurements of the head circumference of the occipital to frontal become more than two standard deviations (SD) below the average for sex and age (Cauchemez et al., 2016). Causes of microcephalus include genetic or environmental factors during pregnancy that affect fetal brain development, prenatal viral infections, mothers consume alcohol, and sometimes have links to hypertension (Mlakar et al.).

The Zika virus detected in the blood ten days after infection or 3-5 days after the onset of symptoms. In pregnant women, the Zika virus can penetrate the placenta. This virus infects and replicates in primary human cells, which according to research have been isolated in the middle of the placenta as well as in the cytotrophoblast villi in the first trimester. Zika virus can infect nerve progenitor cells in the fetus so that it can be a cause of congenital abnormalities (World Health Organization, 2016a). Findings on electron microscopy evidence the strong relationship between Zika virus infection and fetal brain anomalies. The fetal brain appears solid particles in the damaged endoplasmic reticulum. Also visible are grouped structures encased in bright interiors, resembling remnants of the replication complex that is characteristic of flaviviruses. These findings indicate the occurrence of viral replication in the fetal brain (Jamil, Waheed, \& Durrani, 2016).

A midwife is a person who graduated from midwife education that has registered by statutory provisions (Bidan Indonesia). One of the midwives' roles as a helper for normal childbirth is to provide midwifery care through consultation and referral in cases of high-risk pregnancies and emergencies (Safrudin \& Hamidah, 2009). Zika virus infection in pregnancy increases the risk of babies born with microcephalus. The importance of midwives' knowledge of the Zika virus because midwives handle populations with a high risk of being infected with Zika, namely pregnant women. Until now, data on knowledge and practices on Zika virus infection in health workers is still limited, especially midwives. The purpose of this 
study was to determine the knowledge and practice of midwives regarding the Zika virus.

\section{METHODS}

\section{Study design}

This research was a type of quantitative analysis with an analytic observational research design using a cross-sectional study approach to analyze the characteristics of respondents to the knowledge and practice of midwives related to Zika virus in Kendari Indonesia in 2019.

\section{Sample}

The population in this study was midwives who worked at the Kendari City Hospital, Bahteramas Hospitals, and all Kendari City health centers. The sample in this study amounted to 191, selected using a proportional random sampling technique.

\section{Instrument}

Data collection tool used the WHO Knowledge Attitude Practice (KAP) questionnaire (World Health Organization, 2016a) about midwives' knowledge and precautionary measures on Zika virus and various explanatory variables (age, last education, place of work, length of work, religion, ethnicity, marital status, and sources of information). The response variable in this study was knowledge and practice on the Zika virus. Knowledge and practice were measured using a questionnaire consisting of 19 and 10 questions, respectively. Each correct answer was given a score of 1. Each participant's knowledge and practice score are calculated as the total number of responses so that a knowledge score of more than 9.5, and practice of more than 5 indicate good knowledge and activities. Knowledge scores for Zika virus infection ranged from 1 to 19 , and ratings for practice against Zika virus ranged from 1 to 10 . For each respondent, the level of knowledge dichotomized into "good" and "less" based on a $50 \%$ cut-off point (using the highest score reached).

\section{Data analysis}

The relationship between knowledge and practice towards Zika virus infection and explanatory variables assessed using logistic regression. One by one, the explanatory variables were included in the univariate logistic regression and all explanatory variables with P 250.25 . The regression coefficient expressed as an odds ratio (OR) with a 95\% confidence interval (CI).

\section{Ethical consideration}

This study was approved by the Ethics Committee of the Hospital Bahteramas in Southeast Sulawesi Province, Indonesia.

\section{RESULTS}

\section{Characteristics of Respondents}

The number of respondents in this study was 191 respondents. Around $64 \%$ of the respondents were less than 35 years old (Table 1). Most respondents $(78.5 \%)$ were midwives with D3 education level. Around $63 \%$ of the total respondents worked at public health center or called Puskesmas, and $41.3 \%$ of respondents had a working period of 5 to 10 years. As many as $53.9 \%$ of respondents first knew Zika more than one year ago, and $61.8 \%$ of respondents got Zika information through the media.

\section{Knowledge of Zika Virus Infection}

This study shows that $125 \quad(65.4 \%)$ of respondents had good knowledge of Zika virus infection. Variable explanatory variables for age, last education, place of work, length of employment, religion, ethnicity, marital status, and sources of information were associated with knowledge of Zika virus infection based on univariate analysis (Table 1). The multivariate analysis model revealed that only these two factors (workplaces and sources of information) were associated with knowledge of Zika virus infection (Table 2).

Midwives who worked in Puskesmas had better knowledge opportunities for Zika virus infection than midwives who worked in hospitals (OR: 5.130; 95\% CI: 2.591-10.157). Also, midwives who first knew Zika information more than one year ago had a higher chance of having good knowledge than midwives who first knew about Zika on the day the study conducted (OR: 3.030; 95\% CI: 1.485-6.211). 
Table 1 Midwives' Knowledge of Zika Virus Infection in Health Centers and Hospitals in Kendari in $2019(N=191)$

\begin{tabular}{|c|c|c|c|c|}
\hline \multirow{2}{*}{ Variable } & \multirow[b]{2}{*}{ n (\%) } & \multirow{2}{*}{$\begin{array}{c}\text { Good knowledge } \\
\text { n (\%) } \\
\end{array}$} & \multicolumn{2}{|c|}{ Univariate } \\
\hline & & & OR (95\% CI) & p-value \\
\hline \multicolumn{5}{|l|}{ Ages (years) } \\
\hline$>35(\mathrm{R})$ & $69(36.1)$ & $48(25.1)$ & 1 & \\
\hline$\leq 35$ & $122(63.9)$ & $77(40.3)$ & $0.749(0.398-1.407)$ & 0.369 \\
\hline \multicolumn{5}{|l|}{ Education } \\
\hline Diploma 3 (R) & $150(78.5)$ & $93(48.7)$ & 1 & \\
\hline Diploma 4 & $13(6.8)$ & $10(5.2)$ & $2.045(0.539-7.752)$ & 0.293 \\
\hline Strata 1 (Bachelor) & $24(12.6)$ & $19(9.9)$ & $2.331(0.824-6.579)$ & 0.111 \\
\hline Strata 2 (Master) & $4(2.1)$ & $3(1.6)$ & $1.838(0.187-18.182)$ & 0.602 \\
\hline \multicolumn{5}{|l|}{ Work place } \\
\hline Hospital (R) & $71(37.2)$ & $29(15.2)$ & 1 & \\
\hline Public health center & $120(62.8)$ & $96(50.3)$ & $5.793(3.021-11.110)$ & 0.000 \\
\hline \multicolumn{5}{|l|}{ Length of the work } \\
\hline$<5$ year $(\mathrm{R})$ & $28(18.1)$ & $21(13.5)$ & 1 & \\
\hline $5-10$ year & $64(41.3)$ & $45(29.0)$ & $0.789(0.288-2.165)$ & 0.646 \\
\hline$>10$ year & $63(40.6)$ & $40(25.8)$ & $0.579(0.214-1.572)$ & 0.284 \\
\hline \multicolumn{5}{|l|}{ Religion } \\
\hline Islam (R) & $179(93.7)$ & $119(62.3)$ & 1 & \\
\hline Christian & $9(4.7)$ & $6(3.1)$ & $1.008(0.243-4.166)$ & 0.991 \\
\hline Hindu & $3(1.6)$ & 0 & $0.312(0.000)$ & 0.999 \\
\hline \multicolumn{5}{|l|}{ Tribe } \\
\hline Southeast Sulawesi Native (R) & $122(63.9)$ & $79(41.4)$ & 1 & \\
\hline Others & $69(36.1)$ & $46(24.1)$ & $1.088(0.583-2.028)$ & 0.789 \\
\hline \multicolumn{5}{|l|}{ Marriage status } \\
\hline No marriage (R) & $43(22.5)$ & $30(15.7)$ & 1 & \\
\hline Marriage & $148(77.5)$ & $95(49.7)$ & $0.777(0.373-1.616)$ & 0.499 \\
\hline \multicolumn{5}{|l|}{ First time knowing of Zika } \\
\hline Today (R) & $68(35.6)$ & $32(16.8)$ & 1 & \\
\hline$>1$ year & $103(53.9)$ & $80(41.9)$ & $3.906(2.012-7.634)$ & 0.000 \\
\hline Past 1 year & $20(10.5)$ & $13(6.8)$ & $2.087(0.742-5.882)$ & 0.163 \\
\hline \multicolumn{5}{|l|}{ Zika information sources } \\
\hline $\begin{array}{l}\text { When the questionnaire was } \\
\text { distributed (R) }\end{array}$ & $68(35.6)$ & $32(16.8)$ & 1 & \\
\hline Media & $118(61.8)$ & $88(46.1)$ & $3.300(1.754-6.211)$ & 0.000 \\
\hline From people & $5(2.6)$ & $5(2.6)$ & $0.000(0.000)$ & 0.999 \\
\hline
\end{tabular}

Table 2. Multivariate Logistic Regression Analysis to Demonstrate Prediction of Midwives Knowledge of Zika Virus Infection in Health Centers and Hospitals in Kendari in 2019

\begin{tabular}{lcc}
\hline \multirow{2}{*}{ Variable } & Multivariate \\
\cline { 2 - 3 } & OR (95\% CI) & P-value \\
\hline Workplace & 1 & \\
$\quad$ Public health center (R) & $5.130(2.591-10.157)$ & 0.000 \\
$\quad$ Hospital & 1 & \\
\hline First time knowing of Zika & $3.030(1.485-6.211)$ & 0.002 \\
$\quad$ Today (R) & $1.247(0.407-3.817)$ & 0.700 \\
> 1 year & \\
Past 1 year &
\end{tabular}

Practice Against Zika Virus Infection

In total, only $152(79.6 \%)$ of respondents had right effects against Zika virus infection. This study shows that, the explanatory variables of age, last education, place of work, length of employment, religion, ethnicity, marital status, and information sources were associated with practice against Zika virus infection based on univariate analysis (Table 3). The multivariate analysis model was not performed because there were no explanatory variables whose p-values were less than 0.025 . 
Table 3. Univariate Logistic Regression Analysis to Demonstrate Prediction of Midwife Practice Related to Zika Virus Infection in Health Centers and Hospitals in Kendari in $2019(N=191)$

\begin{tabular}{|c|c|c|c|c|}
\hline \multirow{2}{*}{ Variables } & \multirow{2}{*}{ n (\%) } & \multirow{2}{*}{ Good practice n (\%) } & \multicolumn{2}{|c|}{ Univariate } \\
\hline & & & OR (95\% CI) & p-value \\
\hline \multicolumn{5}{|l|}{ Age (years) } \\
\hline$>35(\mathrm{R})$ & $69(36.1)$ & $57(29.8)$ & 1 & \\
\hline$\leq 35$ & $122(63.9)$ & $95(49.7)$ & $0.741(0.348-1.577)$ & 0.436 \\
\hline \multicolumn{5}{|l|}{ Education } \\
\hline Diploma 3 (R) & $150(78.5)$ & $119(62.3)$ & 1 & \\
\hline Diploma 4 & $13(6.8)$ & $11(5.8)$ & $1.432(0.301-6.802)$ & 0.651 \\
\hline Strata 1 (Bachelor) & $24(12.6)$ & $19(9.9)$ & $0.990(0.342-2.865)$ & 0.985 \\
\hline Strata 2 (Master) & $4(2.1)$ & $3(1.6)$ & $3.571(0.078-7.751)$ & 0.833 \\
\hline \multicolumn{5}{|l|}{ Work place } \\
\hline Hospital (R) & $71(37.2)$ & $54(28.3)$ & 1 & \\
\hline Public health center & $120(62.8)$ & $98(51.3)$ & $1.402(0.686-2.866)$ & 0.354 \\
\hline \multicolumn{5}{|l|}{ Length of work (years) } \\
\hline$<5(\mathrm{R})$ & $28(18.1)$ & $21(13.5)$ & 1 & \\
\hline $5-10$ & $64(41.3)$ & $50(32.3)$ & $1.191(0.420-3.367)$ & 0.743 \\
\hline$>10$ & $63(40.6)$ & $53(34.2)$ & $1.767(0.594-5.263)$ & 0.306 \\
\hline \multicolumn{5}{|l|}{ Religion } \\
\hline Islam (R) & $179(93.7)$ & $144(75.4)$ & 1 & \\
\hline Christian & $9(4.7)$ & $7(3.7)$ & $0.850(0.169-4.273)$ & 0.844 \\
\hline Hindu & $3(1.6)$ & $1(0.5)$ & $0.122(0.011-1.379)$ & 0.089 \\
\hline \multicolumn{5}{|l|}{ Tribe } \\
\hline Southeast Sulawesi & $122(63.9)$ & $98(51.3)$ & 1 & \\
\hline $\begin{array}{l}\text { Native }(\mathrm{R}) \\
\text { Others }\end{array}$ & $69(36.1)$ & $52(28.3)$ & $0.882(0.427-1.821)$ & 0.734 \\
\hline \multicolumn{5}{|l|}{ Marital status } \\
\hline Not married (R) & $43(22.5)$ & $32(16.8)$ & 1 & \\
\hline Married & $148(77.5)$ & $120(62.8)$ & $\begin{array}{c}1.473(0.663-3.279 \\
1.509)\end{array}$ & 0.342 \\
\hline \multicolumn{5}{|l|}{ First time knowing Zika } \\
\hline Today (R) & $68(35.6)$ & $50(26.2)$ & 1 & \\
\hline$>1$ year & $103(53.9)$ & $88(46.1)$ & $2.114(0.979-4.545)$ & 0.056 \\
\hline past 1 year & $20(10.5)$ & $14(7.3)$ & $0.840(0.280-2.519)$ & 0.756 \\
\hline \multicolumn{5}{|l|}{ Zika information sources } \\
\hline $\begin{array}{l}\text { When the questionnaire } \\
\text { was distributed }(\mathrm{R})\end{array}$ & $68(35.6)$ & $50(26.2)$ & 1 & \\
\hline Media & $118(61.8)$ & $98(51.3)$ & $1.764(0.857-3.636)$ & 0.123 \\
\hline From people & $5(2.6)$ & $4(2.1)$ & $1.441(0.151-13.698)$ & 0.751 \\
\hline
\end{tabular}

\section{DISCUSSION}

Until now, the Zika virus outbreak has not been reported in Kendari city, Indonesia. However, it is susceptible to the Zika outbreak, given that there is already evidence that shows that the Zika virus already existed in Indonesia. On 1 February 2016, Zika virus infection was declared a public health emergency of international concern by the World Health Organization (WHO). Indonesia is one of the largest dengue-endemic countries that has experienced several outbreaks of chikungunya fever and is widely inhabited by A. aegypti and A. Albopictus mosquitoes (Harapan et al., 2017). The importance of knowledge in health workers related to the Zika virus, especially midwives. As we know, midwives handle populations at high risk of developing Zika, pregnant women. But until now the data on knowledge and practice of Zika virus infection in health workers is still limited, especially midwives.

This study showed that of all explanatory variables, only the place of work and sources of information had a relationship with knowledge. However, related to the practice of the Zika virus, none of the explanatory variables had a relationship with the Zika virus. 
This study showed that knowledge about the Zika virus was associated with the place of work for the first time the respondent knew about Zika. The dominant factor associated with good knowledge was respondents who worked at the Puskesmas, where midwives who worked at the Puskesmas had 5 times the opportunity to have good knowledge compared to midwives who worked at the Hospital. This is possible because the Puskesmas is a health service facility that organizes public health efforts and first-level individual health efforts, by prioritizing promotive and preventive efforts (Mujiati \& Yuniar, 2017).

This study also showed that respondents who first knew Zika more than 1 year ago had a positive relationship with good knowledge compared to respondents who first identified Zika at the time the study conducted. This is possible because the extraordinary events of the Zika virus occurred in 2016 and because the Zika virus itself has never been reported in Kendari so that information related to the Zika virus appears more in 2016 and more respondents access information when Zika declared as an outbreak only. But the reason for this observation is still unclear.

Regarding other explanatory variables such as age, a study found that knowledge of the Zika virus was negatively related to young pregnant women in the United States (Heitzinger, Thoroughman, \& Porter, 2018). This shows that the reason for age is not associated with knowledge is possible due to a lack of exposure or access to information related to the Zika virus. This study also shows that educational attainment was not associated with knowledge of Zika virus infection. There might be two explanations, and the first Zika infection is a contagious disease that only appeared in 2016 and has not yet been endemic in Kendari City. The second reason, in this study, most of the respondents' sources of information about Zika were obtained through the media. The relationship between practice with Zika virus infection showed that there were no explanatory variables associated with lawsuits against Zika virus. This is possible because the respondent's response related to the practice of Zika virus refers more to the prevention and control of vectors, which, although the Zika vector is endemic, there has not yet been a case of Zika virus infection found in Kendari City.

This study revealed that knowledge and practice on Zika virus infection in midwives in Kendari City were considered quite good. But it is still necessary to increase knowledge of midwives related to Zika virus in Kendari city and other regions in Indonesia as one of the preventive measures for Zika virus infection in health workers.

\section{CONCLUSION}

Knowledge and practice regarding Zika virus infection in midwives in Kendari city were relatively good. Furthermore, midwives who worked in the public health center had a five times chance compared to midwives who worked in hospitals to have better knowledge related to the Zika virus. And midwives who first learned about the Zika virus in the past few years had a three times chance compared to midwives who worked in hospitals to have better knowledge related to Zika virus. There were no significant explanatory variables with midwives' practice on Zika virus.

Declaration of Conflicting Interests

We declare that we have no conflict of interests.

References

Bidan Indonesia. Kegiatan Praktikum 2 Standar Profesi Bidan. Hak Cipta $₫$ dan Hak Penerbitan dilindungi Undang-undang, 30.

Cauchemez, S., Besnard, M., Bompard, P., Dub, T., Guillemette-Artur, P., Eyrolle-Guignot, D., . . . Garel, C. (2016). Association between Zika virus and microcephaly in French Polynesia, 2013-15: A retrospective study. The Lancet, 387(10033), 21252132.

Choi, J. S., \& Kim, K. M. (2018). Infection-control knowledge, attitude, practice, and risk perception of occupational exposure to Zika virus among nursing students in Korea: A cross-sectional survey. Journal of Infection and Public Health, 11(6), 840-844.

Duong, V., Dussart, P., \& Buchy, P. (2017). Zika virus in Asia. International Journal of Infectious Diseases, 54, 121-128.

Haddow, A. D., Schuh, A. J., Yasuda, C. Y., Kasper, M. R., Heang, V., Huy, R., . . . Weaver, S. C. (2012). Genetic characterization of Zika virus strains: Geographic expansion of the Asian lineage. PLoS Neglected Tropical Diseases, 6(2), e1477.

Harapan, H., Aletta, A., Anwar, S., Setiawan, A. M., Maulana, R., Wahyuniati, N., .. . Jamil, K. F. (2017). Healthcare workers' knowledge towards Zika virus 
infection in Indonesia: a survey in Aceh. Asian Pacific Journal of Tropical Medicine, 10(2), 189194.

Heitzinger, K., Thoroughman, D. A., \& Porter, K. A. (2018). Knowledge, attitudes, and practices of women of childbearing age testing negative for Zika virus in Kentucky, 2016. Preventive Medicine Reports, 10, 20-23.

Ioos, S., Mallet, H.-P., Goffart, I. L., Gauthier, V., Cardoso, T., \& Herida, M. (2014). Current Zika virus epidemiology and recent epidemics. Medecine et Maladies Infectieuses, 44(7), 302-307.

Jamil, Z., Waheed, Y., \& Durrani, T. Z. (2016). Zika virus, a pathway to new challenges. Asian Pacific Journal of Tropical Medicine, 9(7), 626-629.

Kendrick, C. (2016). Tingkat Pengetahuan virus zika pada mahasiswI Prodi D-3 Kebidanan di STIKes Senior, Medan: Unibersitas Sumatera Utara.

Mlakar, J., Korva, M., Tul, N., Popović, M., PoljšakPrijatelj, M., \& Mraz, J. Zika virus associated with microcephaly. New England Journal of Medicine, 374, 951-958.

Mujiati, M., \& Yuniar, Y. (2017). Ketersediaan sumber daya manusia kesehatan pada fasilitas kesehatan tingkat pertama dalam era jaminan kesehatan nasional di delapan Kabupaten-Kota di Indonesia. Media Penelitian dan Pengembangan Kesehatan, 26(4), 201-210.

Musso, D., Nhan, T., Robin, E., Roche, C., Bierlaire, D., Zisou, K., . . . Broult, J. (2014). Potential for Zika virus transmission through blood transfusion demonstrated during an outbreak in French Polynesia, November 2013 to February 2014. Eurosurveillance, 19(14), 20761.

Noor, R., \& Ahmed, T. (2018). Zika virus: Epidemiological study and its association with public health risk.
Journal of Infection and Public Health, 11(5), 611616.

Painter, J. E., Plaster, A. N., Tjersland, D. H., \& Jacobsen, K. H. (2017). Zika virus knowledge, attitudes, and vaccine interest among university students. Vaccine, 35(6), 960-965.

Perkasa, A., Yudhaputri, F., Haryanto, S., Hayati, R. F., Ma'roef, C. N., Antonjaya, U., . . Rosenberg, R. (2016). Isolation of Zika virus from febrile patient, Indonesia. Emerging Infectious Diseases, 22(5), 924.

Safrudin, \& Hamidah. (2009). Kebidanan komunitas. Jakarta: EGC.

Samuel, G., DiBartolo-Cordovano, R., Taj, I., Merriam, A., Lopez, J. M., Torres, C., . . Gyamfi-Bannerman, C. (2018). A survey of the knowledge, attitudes and practices on Zika virus in New York City. $B M C$ Public Health, 18(1), 98.

Tosepu, R. (2016). Zika Virus: Public Health Notice. Public Health of Indonesia, 2(3), 138-140.

World Health Organization. (2016a). Knowledge, attitudes and practice surveys: Zika virus disease and potential complications: Resource pack. Geneva: World Health Organization.

World Health Organization. (2016b). Situation report: Zika virus, microcephaly, Guillain-Barré syndrome. Geneva: World Health Organization.

Cite this article as: Tosepu, R., Patawari, I. E. A. K. N, Lestari, H., Karimuna, S. R., Sety, L. O. M., \& Nirmala, F. (2020). Knowledge and practices of midwives regarding zika virus in Kendari, Southeast Sulawesi, Indonesia. Public Health of Indonesia, 6(3), 78-84. https://dx.doi.org/10.36685/phi.v6i3.344 